\title{
Rhizosemiotic Play and the Generativity of Fiction
}

\author{
NOEL GOUGH \\ La Trobe University (Australia)
}

I write because I want to find something out ... to learn something that I did not know before I wrote it. (Laurel Richardson, 2001, p. 35)

In this brief essay, I share some experiences of writing 'to find something out' by focusing on a process that I have deployed in three narrative experiments inspired by Gilles Deleuze and Félix Guattari's (1987) figuration of the rhizome-a process that I characterize as rhizosemiotic play. My 'reports' of these experiments are available elsewhere (Gough, 2004, 2006, 2007), and my intention here is simply to demonstrate some textual strategies that I use in performing such experiments, with particular reference to the generativity of intertextual readings of selected fictions in catalyzing them.

\section{RhizomANTics}

I began 'RhizomANTically becoming-cyborg: performing posthuman pedagogies' (Gough, 2004) as follows:

Make a rhizome. But you don't know what you can make a rhizome with, you don't know which subterranean stem is going to make a rhizome, or enter a becoming, people your desert. So experiment. (Deleuze \& Guattari, 1987)

So I shall. This paper is a narrative experiment inspired by Deleuze and Guattari's (1987) figuration of the rhizome. It is a textual assemblage of 
popular and academic ${ }^{1}$ representations of cyborgs that I hope might question, provoke and challenge some of the dominant discourses and assumptions of curriculum, teaching and learning.

Emboldened by Deleuze's penchant for inventing new terms for his figurations, ${ }^{2}$ I have coined the term 'rhizomANTic' (sometimes 'rhizomantic') to name a methodological disposition that connects Deleuze's rhizomatics, ANT (actor-network theory), and Donna Haraway's (1997) 'invented category of semANTics, diffractions' (p. 16, my caps.). ${ }^{3}$ Diffraction is 'an optical metaphor for the effort to make a difference in the world' (p.16), which Haraway (1994) also represents by the activity of making a 'cat's cradle' - a metaphor that imagines the performance of sociotechnical relations as a less orderly and less functionalist activity than the word 'network' often conveys. As my reference to Haraway's work suggests, my engagement with ANT leans towards those aspects of the theory that John Law (1999) characterizes as 'after-ANT'. In an annotated bibliography on Law's ANT Resource Home Page, he refers to Haraway's (1997) Modest_Witness@Second_Millennium. FemaleMan@_Meets_ OncoMouse ${ }^{\mathrm{TM}}$ as 'the best-known example of the different and partially related radical feminist technoscience alternative to actor-network theory. The "after-ANT" studies in this resource in many cases owe as much or more to Haraway as to ANT itself' ${ }^{4}$

I also use the term rhizomantic because much of this essay is about ants. (Gough 2004, p. 253)

Why ants? Ants came to my rescue when I was struggling to expand a hastily written abstract into a presentable conference paper. My abstract, titled 'Becoming-cyborg: performing posthuman pedagogies', did little more than point to the proliferation of cyborg bodies and identities in sites of educational practice and signal my intention to draw on theoretical frameworks provided by Deleuze and ANT to explore the pedagogical implications of this proliferation. I wrote (with unwarranted confidence) that my paper would 'demonstrate how a becoming-cyborg teacher might deploy popular and theoretical conceptions of cyborgs as heuristics in educational work', but I had very few ideas about how I might do this.

In searching recent literature on cyborgs and education I found 'A manifesto for cyborg pedagogy?' by Tim Angus, Ian Cook and James Evans (2001), an account of teaching a university course that was explicitly grounded in ANT. I was impressed by the authors' thoughtful theorizing of cyborg pedagogy but I was curious as to how Deleuzean (con)figurations might 'add value' to their approach. That was when the ants appearedfrom several directions simultaneously. In retrospect, I can only surmise that my frequent reading of the acronym 'ANT' brought them out of the recesses of my memory into the forefront of my consciousness.

I recalled the theoretical ants in Deleuze and Guattari's (1987) 
recollections of writing A Thousand Plateaus-'we watched lines leave one plateau and proceed to another like columns of tiny ants' (p. 22) - and in Pat O'Riley's (2003) description of rhizomes as being 'like crabgrass, ants, wolf packs, and children' (p. 27). But the ants that clamored more insistently for my attention were those that populated some of my favorite fictions, such as Philip K. Dick's (1991/1969) short story, 'The electric ant', and Rudy Rucker's (1994) novel, The Hacker and the Ants.

The most generative fictional ant came from Jerry Prosser's (1992) graphic novel, Cyberantics, which purports to be an annotated version of an illustrated children's book written by an eccentric cyberneticist as a report of his achievements in building (and setting loose) a cybernetic ant. Cyberantics is an ingenious (and very amusing) metafiction, a story that, in Patricia Waugh's (1984) words, 'draws attention to its status as an artefact in order to pose questions about the relationship between fiction and reality' (p. 2). As a metafiction Cyberantics functions as a complex system generating multiple interpretations and displays the properties that contemporary science calls chaos and complexity. Thus, it explores and illustrates, in a form accessible to children and adults alike, an important correspondence between postmodern science and literature. As Peter Stoicheff (1991) writes, 'metafiction and scientific chaos [and I would add scientific complexity] are embraced by a larger revolution in contemporary thought that examines the similar roles of narrative, and of investigative procedure, in our "reading" or knowledge of the world' (p. 85). Cyberantics can therefore be understood as an alternative representation of a postmodern science education text. It embeds stories of modern science, a delightful children's story, and a satire suitable for children and adults, within a complex and complicating metafiction that inhabits a conceptual space shared by much postmodernist science and poststructuralist cultural theorizing.

I realized that Cyberantics exemplifies what is missing from Angus et al.'s (2001) manifesto for cyborg pedagogy: their work is cyber without the antics, that is, it lacks the art, paradox and humor that might motivate us to imagine and invent maps of networks that experiment with the real rather than provide mere tracings of it. It is rewarding to note that the authors of this manifesto have also found this critique generative (see Evans et al., 2007).

Without Cyberantics I doubt that I would have coined 'rhizomantic' or appreciated the interpretive possibilities of this neologism. As soon as I wrote 'rhizomantic' as 'rhizomANTic' I realized that it signified concisely my suspicion that ANT cannot wholly be accommodated by rhizomaticsit fits, but it sits a little awkwardly and uncomfortably. I was then able to demonstrate the extent of this fit by comparing Haraway's and actornetwork theorists' approaches to writing cyborgs with each other and with the implications of Deleuze and Guattari's work. 


\section{Fictions as catalysts of rhizosemiotic play}

It is beyond the scope of this brief paper to describe the two other examples of rhizosemiotic play to which I refer in my opening paragraphs. Nevertheless, I want to emphasize that 'fictions' -in the broadest sense of the term-were again crucial. 'Shaking the tree, making a rhizome: towards a nomadic geophilosophy of science education' (Gough, 2006) was inspired by Peter Gabriel and Youssou N'Dour's (1989) song, 'Shaking the tree', which celebrates the women's movement in Africa, and led me to imagine rhizomes 'shaking the tree' of modern Western science education by destabilizing arborescent conceptions of knowledge. Other 'fictions' animating this essay include Salvador Dali's witty sculpture, Homage to Newton, and Amitav Ghosh's (1997) The Calcutta Chromosome: A Novel of Fevers, Delirium, and Discovery, a science fiction thriller that imagines a counter-history (and counter-science) of malaria.

Similarly, 'Changing planes: rhizosemiotic play in transnational curriculum inquiry' (Gough, 2007), was inspired by Ursula Le Guin's (2004) collection of linked science fiction stories, Changing Planes. Le Guin's pun ('planes' refers both to airplanes and to planes of existence) helped me to 'play' with Deleuze and Guattari's argument that modes of intellectual inquiry need to account for the planes of immanence upon which they operate- the preconceptual fields presupposed by the concepts that inquiry creates. Curriculum inquiry currently operates on nationally distinctive planes of immanence, and I speculate that the internationalization of curriculum studies might, therefore, require curriculum scholars to be able to change planes - to move between one plane of immanence and another and/or to transform their own planes.

Each of these essays takes seriously Deleuze's (1994) assertion that a philosophical work should be 'in part a kind of science fiction' (p. xx). However, as I hope I might have demonstrated here, taking Deleuze 'seriously' does not prevent a writer from having a little fun.

\section{Notes}

1. I use the terms 'popular' and 'academic' to register my perceptions of difference across sites of cultural production, not to inscribe a binary distinction.

2. Rosi Braidotti (2000) argues that "the notion of "figurations" - in contrast to the representational function of "metaphors" - emerges as crucial to Deleuze's notion of a conceptually charged use of the imagination' (p. 170).

3. Drawing attention to the ANT in semantics is gratuitous, but if I don't someone else will.

4. http://www.comp.lancs.ac.uk/sociology/antres.html $<19$ April 2003> 


\section{References}

Angus, Tim, Cook, Ian, \& Evans, James. (2001). A manifesto for cyborg pedagogy? International Research in Geographical and Environmental Education, 10(2), 195-201.

Braidotti, Rosi. (2000). Teratologies. In Ian Buchanan \& Claire Colebrook (Eds.), Deleuze and Feminist Theory (pp. 156-172). Edinburgh: Edinburgh University Press.

Deleuze, Gilles. (1994). Difference and Repetition (Paul Patton, Trans.). New York: Columbia University Press.

Deleuze, Gilles, \& Guattari, Félix. (1987). A Thousand Plateaus: Capitalism and Schizophrenia (Brian Massumi, Trans.). Minneapolis: University of Minnesota Press.

Dick, Philip K. (1991/1969). The electric ant. In We Can Remember It For You Wholesale: Volume 5 of the Collected Stories of Philip K. Dick (pp. 290-308). London: Grafton.

Evans, James, Cook, Ian, \& Griffiths, Helen. (2007). Creativity, group pedagogy and social action: a departure from Gough. Educational Philosophy and Theory, 39. Accessed at Blackwell OnlineEarly http://www.blackwell-synergy.com/doi/ abs/10.1111/j.1469-5812.2007.00334.x

Gabriel, Peter, \& N'Dour, Youssou. (1989). Shaking the tree [Song]. London/Paris: Peter Gabriel Ltd/Editions Virgin Musique.

Ghosh, Amitav. (1997). The Calcutta Chromosome: A Novel of Fevers, Delirium and Discovery. New York: Avon Books.

Gough, Noel. (2004). RhizomANTically becoming-cyborg: performing posthuman pedagogies. Educational Philosophy and Theory, 36(3), 253-265.

Gough, Noel. (2006). Shaking the tree, making a rhizome: towards a nomadic philosophy of science education. Educational Philosophy and Theory, 38(5), 625-645.

Gough, Noel. (2007). Changing planes: rhizosemiotic play in transnational curriculum inquiry. Studies in Philosophy and Education, 26(3), 279-294.

Haraway, Donna J. (1994). A game of cat's cradle: science studies, feminist theory, cultural studies. Configurations: A Journal of Literature, Science, and Technology, 2(1), 59-71.

Haraway, Donna J. (1997).Modest_Witness@Second_Millennium.FemaleMan@_Meets _OncoMouse ${ }^{\mathrm{TM}}$ : Feminism and Technoscience. New York and London: Routledge.

Law, John. (1999). After ANT: topology, naming and complexity. In John Law \& John Hassard (Eds.), Actor Network Theory and After (pp. 1-14). Oxford: Blackwell.

Le Guin, Ursula K. (2004). Changing Planes. London: Victor Gollancz.

O'Riley, Patricia A. (2003). Technology, Culture, and Socioeconomics: A Rhizoanalysis of Educational Discourses. New York: Peter Lang.

Prosser, Jerry (Ed.). (1992). Cyberantics (Annotated Edition; original work ostensibly written by Stanislaw Mayakovsky and illustrated by Rick Geary). New York: Dark Horse Comics.

Richardson, Laurel. (2001). Getting personal: writing-stories. International Journal of Qualitative Studies in Education, 14(1), 33-38.

Rucker, Rudy. (1994). The Hacker and the Ants. New York: Avon Books.

Stoicheff, Peter. (1991). The chaos of metafiction. In N. Katherine Hayles (Ed.), Chaos and Order: Complex Dynamics in Literature and Science (pp. 85-99). Chicago: University of Chicago Press.

Waugh, Patricia. (1984). Metafiction: The Theory and Practice of Self-Conscious Fiction. London: Methuen. 


\section{About the Author}

Noel Gough is Foundation Professor of Outdoor and Environmental Education at La Trobe University, Australia. His current research focuses on the diverse implications of globalization, internationalization and multiculturalism for education, and on refining poststructuralist research methodologies in education, with particular reference to curriculum inquiry, environmental education, and science education. [email: n.gough@latrobe.edu.au]

(C) Copyright 2007. The author, Noel Gough, assigns to the University of Alberta and other educational and non-profit institutions a non-exclusive license to use this document for personal use and in courses of instruction provided that the article is used in full and this copyright statement is reproduced. The authors also grant a non-exclusive license to the University of Alberta to publish this document in full on the World Wide Web, and for the document to be published on mirrors on the World Wide Web. Any other usage is prohibited without the express permission of the author. 